\title{
Metal Oxide Thin-Film Heterojunctions for Photovoltaic Applications
}

\author{
Ørnulf Nordseth ${ }^{1, *}$, Raj Kumar ${ }^{2}$, Kristin Bergum ${ }^{2}$, Laurentiu Fara ${ }^{3,4}{ }^{(0)}$, Constantin Dumitru ${ }^{3}$, \\ Dan Craciunescu ${ }^{3}$, Florin Dragan ${ }^{3}$, Irinela Chilibon ${ }^{5}$, Edouard Monakhov ${ }^{2}$, Sean Erik Foss ${ }^{1}$ \\ and Bengt Gunnar Svensson ${ }^{2}$ \\ 1 Institute for Energy Technology (IFE), P.O. Box 40, NO-2027 Kjeller, Norway; Sean.Foss@ife.no \\ 2 Department of Physics/Center for Materials Science and Nanotechnology (SMN), University of Oslo, P.O. \\ Box 1048, Blindern, NO-0316 Oslo, Norway; raj.kumar@smn.uio.no (R.K.); \\ kristin.bergum@smn.uio.no (K.B.); edouard.monakhov@fys.uio.no (E.M.); b.g.svensson@fys.uio.no (B.G.S.) \\ 3 Department of Physics, Faculty of Applied Sciences, Polytechnic University of Bucharest, Spl. Independentei \\ 313, RO-060042 Bucharest, Romania; lfara@renerg.pub.ro (L.F.); condumitru@yahoo.com (C.D.); \\ dan.craciunescu@sdettib.pub.ro (D.C.); florin.dragan@sdettib.pub.ro (F.D.) \\ 4 Academy of Romanian Scientists, Spl. Independentei 54, RO-030167 Bucharest, Romania \\ 5 National Institute of Research and Development for Optoelectronics (INOE-2000), Bucharest-Magurele, Str. \\ Atomiștilor 409, RO-077125 Măgurele, Romania; qilib@yahoo.com \\ * Correspondence: ornulf.nordseth@ife.no; Tel.: +47-6380-6000
}

Received: 9 November 2018; Accepted: 6 December 2018; Published: 19 December 2018

check for updates

\begin{abstract}
Silicon-based tandem solar cells incorporating low-cost, abundant, and non-toxic metal oxide materials can increase the conversion efficiency of silicon solar cells beyond their conventional limitations with obvious economic and environmental benefits. In this work, the electrical characteristics of a metal oxide thin-film heterojunction solar cell based on a cuprous oxide $\left(\mathrm{Cu}_{2} \mathrm{O}\right)$ absorber layer were investigated. Highly Al-doped n-type $\mathrm{ZnO}(\mathrm{AZO})$ and undoped p-type $\mathrm{Cu}_{2} \mathrm{O}$ thin films were prepared on quartz substrates by magnetron sputter deposition. The electrical and optical properties of these thin films were determined from Hall effect measurements and spectroscopic ellipsometry. After annealing the $\mathrm{Cu}_{2} \mathrm{O}$ film at $900{ }^{\circ} \mathrm{C}$, the majority carrier (hole) mobility and the resistivity were measured at $50 \mathrm{~cm}^{2} / \mathrm{V} \cdot \mathrm{s}$ and $200 \Omega \cdot \mathrm{cm}$, respectively. Numerical modeling was carried out to investigate the effect of band alignment and interface defects on the electrical characteristics of the $\mathrm{AZO} / \mathrm{Cu}_{2} \mathrm{O}$ heterojunction. The analysis suggests that the incorporation of a buffer layer can enhance the performance of the heterojunction solar cell as a result of reduced conduction band offset.
\end{abstract}

Keywords: cuprous oxide; thin film; magnetron sputtering; heterojunction; modelling; band alignment; interface defects

\section{Introduction}

The photovoltaic (PV) market is currently dominated by wafer-based crystalline silicon solar cells, with a market share of more than 90\% [1]. Further cost reductions for this technology can be achieved by developing silicon-based tandem solar cells employing low-cost, abundant, and non-toxic metal oxide materials [2]. Among these metal oxides is cuprous oxide $\left(\mathrm{Cu}_{2} \mathrm{O}\right)$, which is considered an attractive material for photovoltaic applications since it is a p-type semiconductor with high optical absorption and a direct bandgap of about $2.1 \mathrm{eV}$, yielding a theoretical power conversion efficiency limit close to $20 \%$ under 1 sun illumination [3]. To construct a metal oxide $\mathrm{p}-\mathrm{n}$ heterojunction, $\mathrm{Cu} \mathrm{u}_{2} \mathrm{O}$ can be combined with various n-type oxide materials, such as for example $\mathrm{ZnO}$, and accordingly, one can foresee a heterojunction solar cell fully based on low-cost metal oxides. However, the highest conversion efficiency currently achieved experimentally for the $\mathrm{n}-\mathrm{ZnO} / \mathrm{p}-\mathrm{Cu}_{2} \mathrm{O}$ heterojunction solar 
cell is only $8.1 \%$ [4], which suggests that further investigation of $\mathrm{Cu}_{2} \mathrm{O}$-based solar cells is required in order to realize their full potential in photovoltaic applications.

For $\mathrm{ZnO} / \mathrm{Cu}_{2} \mathrm{O}$ heterojunction solar cells, the properties of the heterojunction interface are critical in order to obtain high power conversion efficiency. For instance, reducing the defect density at the heterojunction interface to a minimum is important in order to avoid recombination losses. Unfortunately, the small enthalpy of formation for $\mathrm{Cu}_{2} \mathrm{O}(\sim 170 \mathrm{~kJ} / \mathrm{mol})$ makes the interface prone to oxidation, e.g., a few $\mathrm{nm}$ thick intermediate $\mathrm{CuO}$ layer was reported to form at the $\mathrm{ZnO} / \mathrm{Cu}_{2} \mathrm{O}$ interface [5], which may severely affect the current transport in $\mathrm{Cu}_{2} \mathrm{O}$-based heterojunction devices since the defect density in this thin interface layer is typically much higher than that of the bulk $\mathrm{Cu}_{2} \mathrm{O}$ layer. Furthermore, the relatively low electron affinity of $\sim 3.2 \mathrm{eV}$ for $\mathrm{Cu}_{2} \mathrm{O}$ makes alignment of the energy bands challenging for $\mathrm{ZnO} / \mathrm{Cu}_{2} \mathrm{O}$ heterojunction solar cells. For example, $\mathrm{ZnO}$ features a conduction and valence band misalignment with $\mathrm{Cu}_{2} \mathrm{O}$ of approximately 1 and $2.3 \mathrm{eV}$, respectively, causing a reduced open-circuit voltage $\left(V_{o c}\right)$ for the heterojunction solar cell [6]. To accommodate this band offset, it is possible to introduce a buffer layer between the $\mathrm{ZnO}$ and $\mathrm{Cu}_{2} \mathrm{O}$ layers in the heterojunction structure with the aim of improving the charge carrier transport properties of the heterojunction by reducing the band misalignment. Introduction of a buffer layer has shown to improve the power conversion efficiency of experimentally realized $\mathrm{ZnO} / \mathrm{Cu}_{2} \mathrm{O}$ heterojunction solar cells in the last decade [7], e.g., for the $8.1 \%$ record cell utilization of a $\mathrm{Zn}_{1-x} \mathrm{Ge}_{\mathrm{x}} \mathrm{O}$ buffer layer led to a significant improvement in device performance due to a reduction of the conduction band offset [4], but still, there is a rather large $V_{o c}$ deficit relative to the absorber bandgap suggesting that controlling the conduction band offset is essential in order to enhance the device performance [8]. Since the energy band alignment can be considerably affected by defects present at the heterojunction interface as well, it is important to understand the role of interface defects on the electrical characteristics of the heterojunction solar cell [9].

The objective of this work is to evaluate the electrical performance of a heterojunction solar cell based on $\mathrm{Al}$-doped $\mathrm{ZnO}(\mathrm{AZO})$ and $\mathrm{Cu}_{2} \mathrm{O}$ thin films using numerical modelling. Device simulation is a prerequisite for designing efficient solar cells and for understanding the fundamental physical mechanisms, such as charge carrier transport and recombination. To this end, we have developed a device model for the $\mathrm{AZO} / \mathrm{Cu}_{2} \mathrm{O}$ heterojunction using technology computer-aided design (TCAD) software, i.e., Silvaco Atlas. Material properties for sputter-deposited $\mathrm{AZO}$ and $\mathrm{Cu}_{2} \mathrm{O}$ thin films on quartz substrate were obtained from experimental characterization and implemented in the numerical model. Using this model, we investigate the effect of inserting a buffer layer with various electron affinity between the $\mathrm{AZO}$ and $\mathrm{Cu}_{2} \mathrm{O}$ layers on the electrical characteristics of the heterojunction solar cell. Moreover, the effect of the density of defects at the heterojunction interface as well as the density of bulk defects for the $\mathrm{Cu}_{2} \mathrm{O}$ absorber layer on the performance of the $\mathrm{AZO} / \mathrm{Cu}_{2} \mathrm{O}$ heterojunction solar cell is analyzed. Current-voltage (I-V) parameters and energy band diagrams for the $\mathrm{AZO} / \mathrm{Cu}_{2} \mathrm{O}$ heterojunction solar cells for different buffer layers and defect densities are presented and discussed. We show that the incorporation of a buffer layer can enhance the performance of the heterojunction solar cell as a result of reduced band offsets and that the energy band diagrams are affected by the defect density at the heterojunction interface.

\section{Materials and Methods}

\subsection{Thin Film Synthesis and Characterization}

$\mathrm{Cu}_{2} \mathrm{O}$ and $\mathrm{AZO}$ thin films were deposited on $10 \times 10 \times 0.5 \mathrm{~mm}^{3}$ quartz substrates using a direct current/radio frequency (DC/RF) magnetron sputtering system (Semicore Triaxis). Then, $500 \mathrm{~nm}$ thick $\mathrm{Cu}_{2} \mathrm{O}$ films were deposited by reactive sputtering of a $99.999 \% \mathrm{Cu}$ target in $\mathrm{O}_{2} / \mathrm{Ar}(6 / 49 \mathrm{sccm})$ at a substrate temperature of $400{ }^{\circ} \mathrm{C}$. The power was fixed at $100 \mathrm{~W}$. As-grown $\mathrm{Cu}_{2} \mathrm{O}$ films were annealed at $900{ }^{\circ} \mathrm{C}$ for $3 \mathrm{~min}$ in vacuum (pressure $\sim 10^{-1}$ Torr). Then, $200 \mathrm{~nm}$ thick AZO films were deposited by co-sputtering of a $99.99 \%$ pure $\mathrm{ZnO}$ ceramic target at $50 \mathrm{~W}$ and a $99.999 \% \mathrm{Al}$ target at $3 \mathrm{~W}$ in $\mathrm{Ar}$ 
at a substrate temperature of $400{ }^{\circ} \mathrm{C}$, yielding an aluminum content of approximately $4 \mathrm{wt} \%$ in the deposited layers. During the magnetron sputtering deposition, the base pressure was below $4.0 \times 10^{-7}$ Torr. The optical properties of the $\mathrm{AZO}$ and $\mathrm{Cu}_{2} \mathrm{O}$ thin films were analyzed using a Horiba Jobin Yvon Uvisel spectroscopic ellipsometer (Horiba Ltd., Kyoto, Japan). The optical transmittance spectrum was measured using a setup with spectrophotometers (Ocean Optics, Largo FL, USA), a deuterium-halogen light source, and an integrating sphere. Room temperature Hall effect measurements (LakeShore 7604) were carried out using the van-der Pauw configuration (Lake Shore Cryotronics, Inc., Westerville, $\mathrm{OH}, \mathrm{USA})$.

\subsection{Device Simulation}

The electrical performance of the $\mathrm{AZO} / \mathrm{Cu}_{2} \mathrm{O}$ heterojunction solar cell with incorporation of different buffer layers was evaluated based on device modeling in Silvaco Atlas [10]. A schematic overview of the AZO/Cu2O heterojunction model is shown in Figure 1. The model assumes the heterojunction as several layers for which the physical properties were based on experimental and theoretical results reported in the literature [11]. Planar (flat) surfaces were adopted in the simulation model and the incident optical spectrum was air mass 1.5 global (AM1.5G). The thickness of the front side AZO layer was set to $100 \mathrm{~nm}$ in order to provide sufficient lateral transport of charge carriers for the solar cell. A buffer layer was inserted between the AZO transparent electrode and the $\mathrm{Cu}_{2} \mathrm{O}$ absorber layer. Additionally, an interface defect layer (IDL) was included between the buffer and $\mathrm{Cu}_{2} \mathrm{O}$ layers in order to represent interface defect states, which significantly influences the electrical characteristics of the $\mathrm{AZO} / \mathrm{Cu}_{2} \mathrm{O}$ heterojunction. A highly doped $\mathrm{Cu}_{2} \mathrm{O}: \mathrm{N}$ back surface layer was introduced at the rear side, forming a $\mathrm{p}+$ back surface field in order to reduce the amount of recombination at the rear surface. The rear $\mathrm{Al}$ metal electrode was assumed to make an ohmic contact to the $\mathrm{Cu}_{2} \mathrm{O}: \mathrm{N}$ back surface layer.

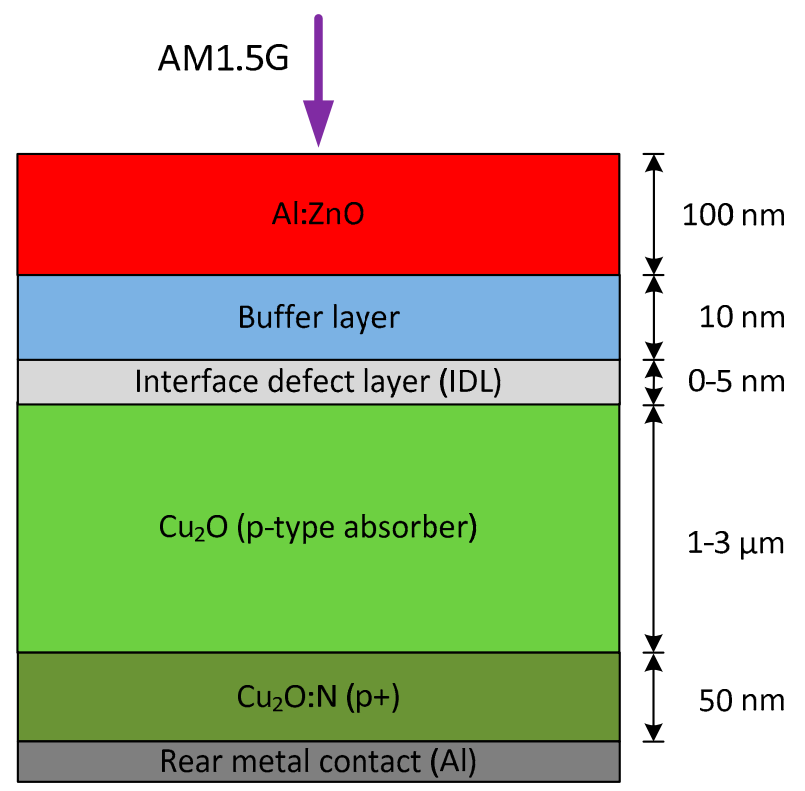

Figure 1. Schematic overview of the Al-doped $\mathrm{ZnO}(\mathrm{AZO}) / \mathrm{Cu}_{2} \mathrm{O}$ heterojunction model implemented in Silvaco Atlas.

Table 1 summarizes the material parameters and corresponding values for each layer implemented in the $\mathrm{AZO} / \mathrm{Cu}_{2} \mathrm{O}$ heterojunction model. Most of the parameter values were acquired from Ref. 11 , except for the carrier mobilities and concentrations for the $\mathrm{AZO}$ and $\mathrm{Cu}_{2} \mathrm{O}$ layers which were experimentally derived from Hall effect measurements. The donor-like defects had a Gaussian distribution with a midgap level and a width of $0.1 \mathrm{eV}$ was assumed for all layers [11]. The complex refractive indices for $\mathrm{AZO}$ and $\mathrm{Cu}_{2} \mathrm{O}$ were obtained by variable angle spectroscopic ellipsometry 
measurements. The reflectance of the incident light at the front surface was set to $5 \%$ whereas the internal reflectance at the rear surface was set to $90 \%$ for the entire wavelength range of the AM1.5G spectrum.

Table 1. Material parameters and corresponding default values used for simulation of the $\mathrm{AZO} / \mathrm{Cu}_{2} \mathrm{O}$ heterojunction in Silvaco Atlas. The asterisk $\left({ }^{*}\right)$ indicates values that were varied in the numerical analysis.

\begin{tabular}{|c|c|c|c|c|c|}
\hline Parameter & AZO & Buffer Layer & IDL & $\mathrm{Cu}_{2} \mathrm{O}$ & $\mathrm{Cu}_{2} \mathrm{O}: \mathrm{N}$ \\
\hline Layer thickness (nm) & 100 & 10 & 0 * & $2000 *$ & 50 \\
\hline Electron affinity $(\mathrm{eV})$ & 4.4 & $3.7^{*}$ & 3.2 & 3.2 & 3.2 \\
\hline Band gap $(\mathrm{eV})$ & 3.35 & 3.35 & 2.1 & 2.1 & 2.1 \\
\hline Relative permittivity & 9 & 9 & 7.6 & 7.6 & 7.6 \\
\hline Acceptor concentration $\left(\mathrm{cm}^{-3}\right)$ & 0 & 0 & $1 \times 10^{15}$ & $1 \times 10^{15}$ & $1 \times 10^{21}$ \\
\hline Donor concentration $\left(\mathrm{cm}^{-3}\right)$ & $4 \times 10^{20}$ & $1 \times 10^{19}$ & 0 & 0 & 0 \\
\hline Hole mobility $\left(\mathrm{cm}^{2} / \mathrm{V} \cdot \mathrm{s}\right)$ & 5 & 5 & 50 & 50 & 50 \\
\hline Electron mobility $\left(\mathrm{cm}^{2} / \mathrm{V} \cdot \mathrm{s}\right)$ & 10 & 10 & 100 & 100 & 100 \\
\hline $\begin{array}{l}\text { Effective density of states in conduction band } \\
\qquad\left(\mathrm{cm}^{-3}\right)\end{array}$ & $2.2 \times 10^{18}$ & $2.2 \times 10^{18}$ & $2.4 \times 10^{19}$ & $2.4 \times 10^{19}$ & $2.4 \times 10^{19}$ \\
\hline Effective density of states in valence band $\left(\mathrm{cm}^{-3}\right)$ & $1.8 \times 10^{19}$ & $1.8 \times 10^{19}$ & $1.3 \times 10^{19}$ & $1.3 \times 10^{19}$ & $1.3 \times 10^{19}$ \\
\hline Capture cross section of holes $\left(\mathrm{cm}^{2}\right)$ & $1 \times 10^{-15}$ & $1 \times 10^{-15}$ & $1 \times 10^{-13}$ & $1 \times 10^{-15}$ & $1 \times 10^{-15}$ \\
\hline Capture cross section of electrons $\left(\mathrm{cm}^{2}\right)$ & $1 \times 10^{-12}$ & $1 \times 10^{-12}$ & $1 \times 10^{-13}$ & $5 \times 10^{-13}$ & $5 \times 10^{-13}$ \\
\hline Defect density (donor-like) $\left(\mathrm{cm}^{-3}\right)$ & $1 \times 10^{18}$ & $5 \times 10^{17}$ & $1 \times 10^{19 *}$ & $1 \times 10^{13 *}$ & $1 \times 10^{13}$ \\
\hline Defect peak energy $(\mathrm{eV})$ & 1.68 & 1.68 & 1.05 & 1.05 & 1.05 \\
\hline Defect distribution width $(\mathrm{eV})$ & 0.1 & 0.1 & 0.1 & 0.1 & 0.1 \\
\hline
\end{tabular}

\section{Results}

\subsection{Optical and Electrical Properties}

Figure 2a shows the complex refractive indices of the $\mathrm{AZO}$ and $\mathrm{Cu}_{2} \mathrm{O}$ thin films in the wavelength range from 300 to $800 \mathrm{~nm}$, as obtained from spectroscopic ellipsometry measurements. The data suggests that high energy photons $(\lambda<550 \mathrm{~nm})$ are absorbed in the $\mathrm{Cu}_{2} \mathrm{O}$ layer. The complex refractive indices for the $\mathrm{AZO}$ and $\mathrm{Cu}_{2} \mathrm{O}$ layers were implemented in the numerical model. Based on the measured transmittance spectra, a Tauc plot analysis was carried out in order to determine the optical band gap of the $\mathrm{AZO}$ and $\mathrm{Cu}_{2} \mathrm{O}$ (as-grown and annealed) thin films [12].
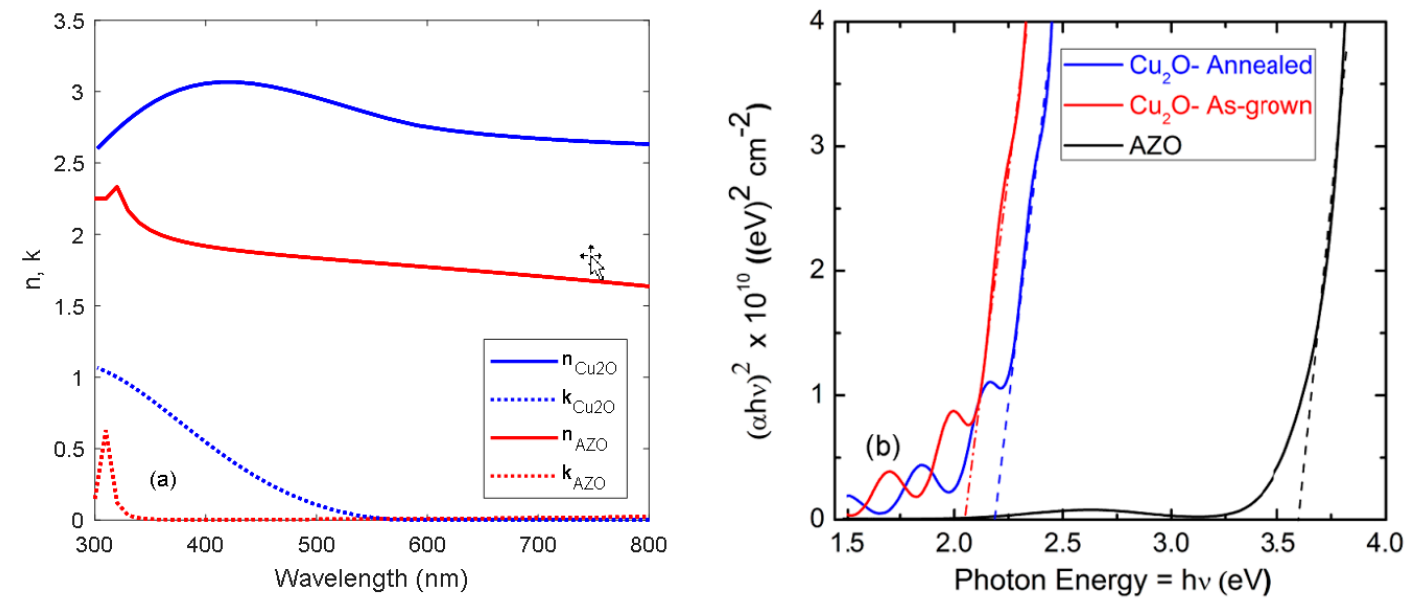

Figure 2. (a) Refractive index and extinction coefficient for $\mathrm{AZO}$ and annealed $\mathrm{Cu}_{2} \mathrm{O}$ thin films deposited on quartz; (b) Tauc plot for the as-grown and annealed $\mathrm{Cu}_{2} \mathrm{O}$ and $\mathrm{AZO}$ thin films deposited on quartz. The optical band gap values are estimated from extrapolation to the abscissa (dashed lines).

Figure $2 \mathrm{~b}$ shows the resulting Tauc plots, which suggest that the optical band gap is increased from $E_{\mathrm{g}}=2.06 \mathrm{eV}$ for the as-grown $\mathrm{Cu}_{2} \mathrm{O}$ film to $E_{\mathrm{g}}=2.19 \mathrm{eV}$ after annealing at $900{ }^{\circ} \mathrm{C}$. The widening of the optical band gap after annealing might be due to partial elimination of defects states [13] and 
more phase-pure $\mathrm{Cu}_{2} \mathrm{O}$ films with negligible contribution of the $\mathrm{CuO}$ phase. For the AZO thin film, the optical band gap was estimated to $E_{\mathrm{g}}=3.61 \mathrm{eV}$, evidencing the so-called Burstein-Moss effect.

The majority carrier mobility and concentration, as well as the film resistivity for AZO and (as-grown and annealed) $\mathrm{Cu}_{2} \mathrm{O}$ thin films deposited on quartz are summarized in Table 2. The data suggests that the electrical properties for the $\mathrm{Cu}_{2} \mathrm{O}$ thin film are enhanced after thermal annealing at $900{ }^{\circ} \mathrm{C}$, i.e., the resistivity decreases from 560 to $200 \Omega \cdot \mathrm{cm}$ and the majority carrier (hole) mobility increases from 10 to $50 \mathrm{~cm}^{2} / \mathrm{V} \cdot \mathrm{s}$ after annealing. These values are comparable to those reported previously for sputter-deposited polycrystalline $\mathrm{Cu}_{2} \mathrm{O}$ thin films on quartz $[14,15]$, suggesting that the annealed $\mathrm{Cu}_{2} \mathrm{O}$ thin films are well suited for photovoltaic applications. The increase in carrier mobility after annealing can, at least partly, be attributed to the increase in grain size and reduced grain-boundary scattering $[16,17]$.

Table 2. Majority carrier mobility and concentration, as well as film resistivity for $\mathrm{AZO}$ and $\mathrm{Cu}_{2} \mathrm{O}$ thin films on quartz, derived from room temperature Hall effect measurements.

\begin{tabular}{cccc}
\hline Parameter & AZO & $\mathbf{C u}_{\mathbf{2}} \mathbf{O}$ & $\mathbf{C u}_{2} \mathbf{O}{ }^{*}$ \\
\hline Mobility $\left(\mathrm{cm}^{2} / \mathrm{V} \cdot \mathrm{s}\right)$ & 20 & 10 & 50 \\
Concentration $\left(\mathrm{cm}^{-3}\right)$ & $3 \times 10^{20}$ & $3 \times 10^{15}$ & $1 \times 10^{15}$ \\
Resistivity $(\mathrm{Ohm} \cdot \mathrm{cm})$ & $5 \times 10^{-4}$ & 560 & 200 \\
\hline & ${ }^{*}$ Annealed at $900^{\circ} \mathrm{C}$.
\end{tabular}

\subsection{Modelling of $\mathrm{AZO} / \mathrm{Cu}_{2} \mathrm{O}$ Heterojunction}

Figure 3a shows the simulated $\mathrm{I}-\mathrm{V}$ curve for the $\mathrm{AZO} / \mathrm{Cu}_{2} \mathrm{O}$ heterojunction solar cell under 1 sun (AM1.5G) illumination. In this case, the default parameter values provided in Table 1 for the different layers constituting the heterojunction structure were implemented, yielding a short circuit current density $\left(J_{\mathrm{sc}}\right)$ of $10.0 \mathrm{~mA} / \mathrm{cm}^{2}$, an open circuit voltage $\left(V_{\mathrm{oc}}\right)$ of $1.48 \mathrm{~V}$, a fill factor $(\mathrm{FF})$ of $84.7 \%$, and a power conversion efficiency $(\eta)$ of $12.5 \%$. Figure $3 \mathrm{~b}$ shows the corresponding simulated external quantum efficiency (EQE) curve for the $\mathrm{AZO} / \mathrm{Cu}_{2} \mathrm{O}$ heterojunction solar cell. The EQE is approximately $90 \%$ in the wavelength range from 400 to $500 \mathrm{~nm}$, in good agreement with the simulated $\mathrm{EQE}$ curve reported previously for a corresponding $\mathrm{AZO} / \mathrm{Cu}_{2} \mathrm{O}$ heterojunction solar cell model [11].
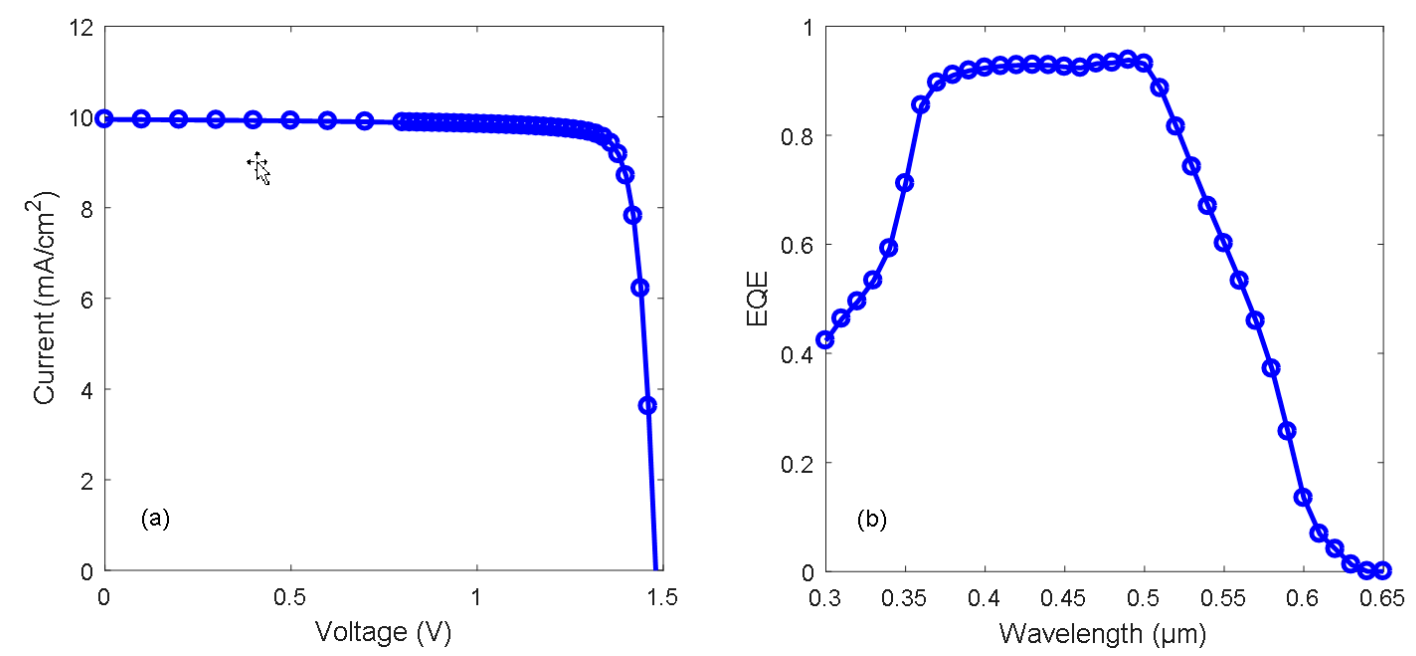

Figure 3. Simulated (a) $\mathrm{I}-\mathrm{V}$ and (b) external quantum efficiency (EQE) curve for the $\mathrm{AZO} / \mathrm{Cu}_{2} \mathrm{O}$ heterojunction solar cell under 1 sun illumination, using the default parameter values listed in Table 1.

\subsubsection{Effect of Buffer Layer Electron Affinity}

Figure $4 \mathrm{a}$ shows the simulated I-V parameters for the $\mathrm{AZO} / \mathrm{Cu}_{2} \mathrm{O}$ heterojunction solar cell as a function of the buffer layer electron affinity, without an interface defect layer included in the structure. 
For the heterojunction with a buffer layer electron affinity $\chi_{\mathrm{b}}=4.4 \mathrm{eV}$, corresponding to that of $\mathrm{AZO}$, a conversion efficiency of 7.2\% was achieved. By introducing a buffer layer with lower electron affinity, the electrical performance was significantly improved, and the highest performance $(\eta=12.5 \%)$ was achieved for a buffer layer electron affinity $\chi_{b}=3.7 \mathrm{eV}$. The corresponding energy band diagram for the $\mathrm{AZO} / \mathrm{Cu}_{2} \mathrm{O}$ heterojunction interface is shown in Figure $4 \mathrm{~b}$, for a buffer layer electron affinity of 3.7 and $4.4 \mathrm{eV}$. $E_{\mathrm{CB}}$ and $E_{\mathrm{VB}}$ correspond to the conduction band minimum energy and valence band maximum energy, respectively. In addition, indicated in Figure $4 \mathrm{~b}$ are the band gap energy offset for the conduction band $\left(\Delta E_{\mathrm{CB}}\right)$ and valence band $\left(\Delta E_{\mathrm{VB}}\right)$ along with the energy band gaps, $E_{\mathrm{g}}$. The band diagram suggests that $\Delta E_{\mathrm{CB}}$ and $\Delta E_{\mathrm{VB}}$ are reduced with the introduction of a buffer layer, i.e., $\Delta E_{\mathrm{CB}}$ is reduced from 1.05 to $0.38 \mathrm{eV}$ and $\Delta E_{\mathrm{VB}}$ is reduced from 2.45 to $1.75 \mathrm{eV}$ when a buffer layer with electron affinity $\chi_{b}=3.7 \mathrm{eV}$ is introduced at the heterojunction interface. As will be discussed in the next section, various thin film materials with electron affinity lower than that of $\mathrm{ZnO}\left(\chi_{\mathrm{ZnO}}=4.4 \mathrm{eV}\right)$ have been implemented as buffer layer in experimentally realized $\mathrm{ZnO} / \mathrm{Cu}_{2} \mathrm{O}$ heterojunction solar cells in order to enhance their electrical performance [6-9].
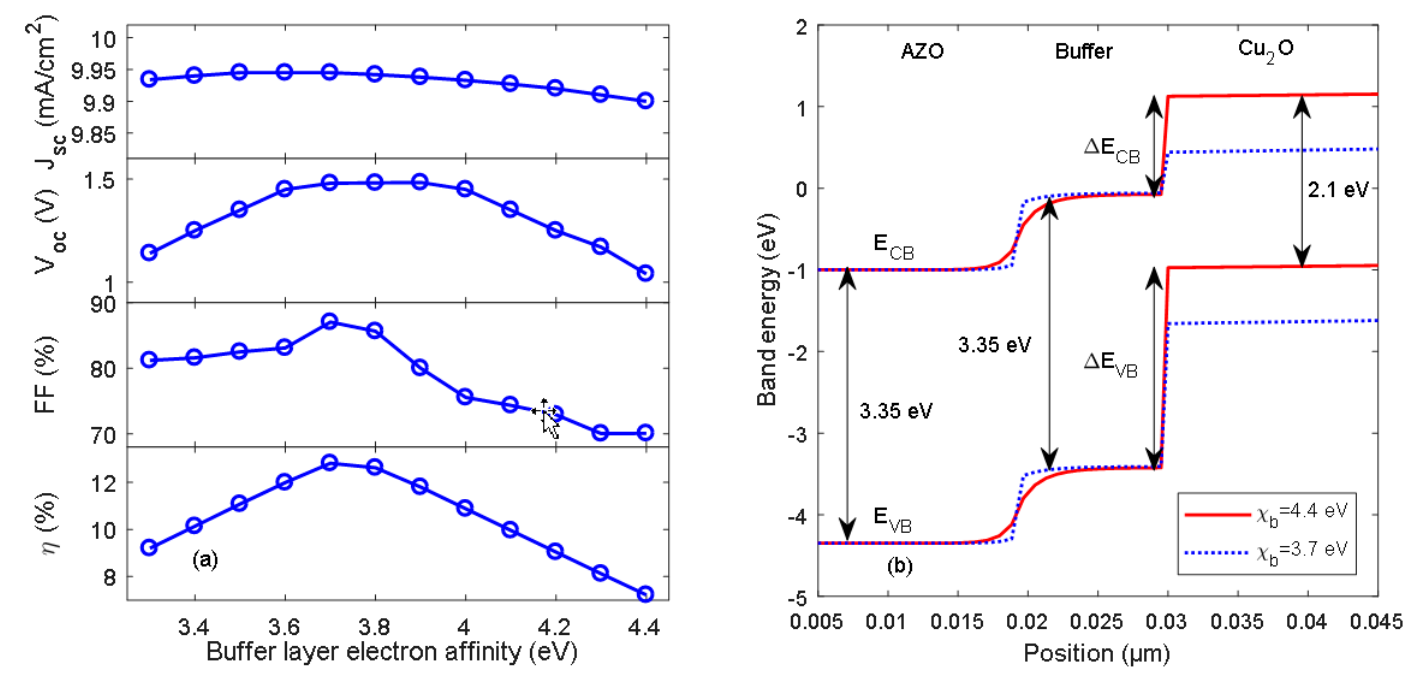

Figure 4. (a) Simulated $\mathrm{I}-\mathrm{V}$ parameters for the $\mathrm{AZO} / \mathrm{Cu}_{2} \mathrm{O}$ heterojunction solar cell as a function of the buffer layer electron affinity. (b) Energy band diagram for the AZO/ $\mathrm{Cu}_{2} \mathrm{O}$ heterojunction interface for a buffer layer electron affinity $\left(\chi_{\mathrm{b}}\right)$ of 3.7 and $4.4 \mathrm{eV}$.

\subsubsection{Effect of Interface Defects}

Figure 5 a shows the simulated $\mathrm{I}-\mathrm{V}$ parameters for the $\mathrm{AZO} / \mathrm{Cu}_{2} \mathrm{O}$ heterojunction solar cell as a function of interface defect density $\left(N_{\mathrm{D}, \mathrm{IDL}}\right)$ for different thicknesses of the interface defect layer $\left(t_{\text {IDL }}\right)$. The defect density and layer thickness were varied in the ranges $1 \times 10^{16}$ to $1 \times 10^{20} \mathrm{~cm}^{-3}$ and 1-5 nm, respectively. The results suggest that the electrical performance is severely affected for an interface defect density $N_{\mathrm{D}, \mathrm{IDL}}>1 \times 10^{18} \mathrm{~cm}^{-3}$, i.e., for $t_{\mathrm{IDL}}=5 \mathrm{~nm}$ the conversion efficiency decreases from $\eta=11.5 \%$ for $N_{\mathrm{D}, \mathrm{IDL}}=1 \times 10^{18} \mathrm{~cm}^{-3}$ to $\eta=0.5 \%$ for $N_{\mathrm{D}, \mathrm{IDL}}>10^{20} \mathrm{~cm}^{-3}$. Figure $5 \mathrm{~b}$ shows the corresponding energy band diagram for the $\mathrm{AZO} / \mathrm{Cu}_{2} \mathrm{O}$ heterojunction interface for $t_{\mathrm{IDL}}=5 \mathrm{~nm}$ and different $N_{D, I D L}$. The magnitude of band bending in the buffer layer and interface defect layer at the heterojunction interface increases with $N_{D, I D L}$. As a result, the energy bands for the $\mathrm{Cu}_{2} \mathrm{O}$ absorber layer are shifted towards higher energies. 

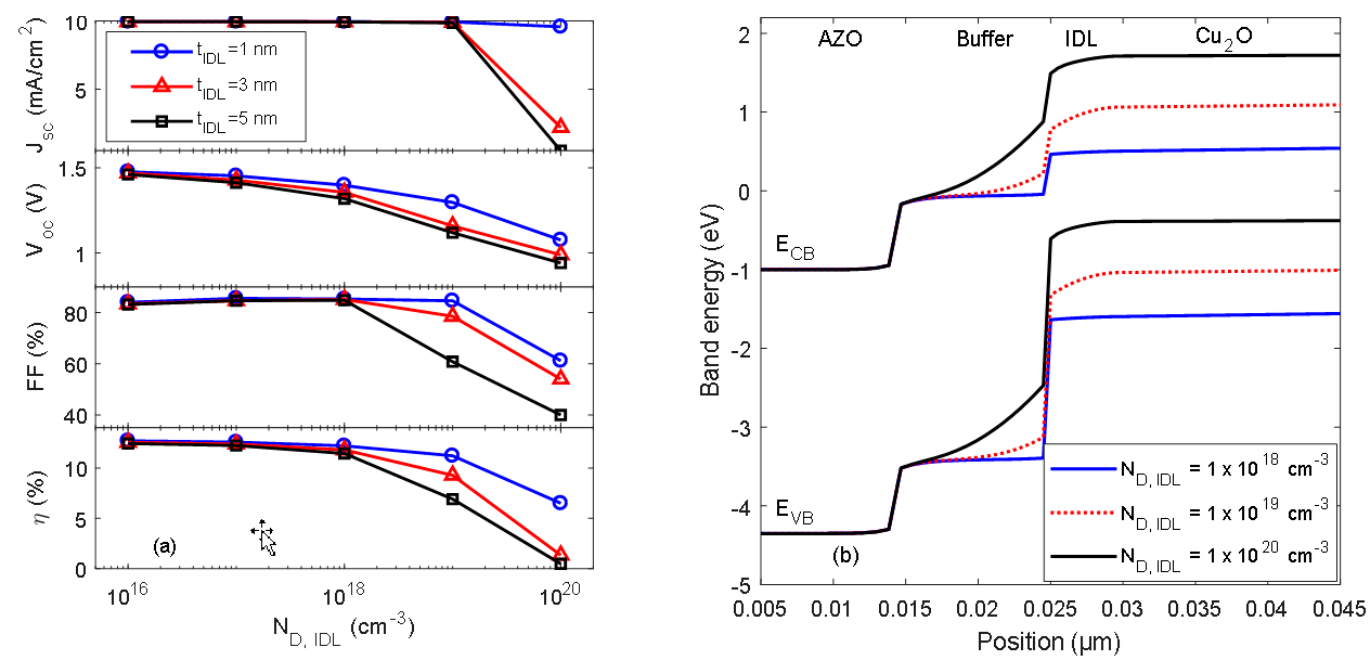

Figure 5. (a) Simulated I-V parameters for the $\mathrm{AZO} / \mathrm{Cu}_{2} \mathrm{O}$ heterojunction solar cell as a function of $N_{\mathrm{D}, \mathrm{IDL}}$ for various interface defect layer thicknesses $\left(t_{\mathrm{IDL}}\right) ;(\mathbf{b})$ energy band diagram for the $\mathrm{AZO} / \mathrm{Cu}_{2} \mathrm{O}$ heterojunction interface for various $N_{\mathrm{D}}$, IDL with $t_{\mathrm{IDL}}=5 \mathrm{~nm}$.

\subsubsection{Effect of $\mathrm{Cu}_{2} \mathrm{O}$ Bulk Defects}

Figure $6 \mathrm{a}$ shows the simulated $\mathrm{I}-\mathrm{V}$ parameters for the $\mathrm{AZO} / \mathrm{Cu}_{2} \mathrm{O}$ heterojunction solar cell as a function of $\mathrm{Cu}_{2} \mathrm{O}$ bulk defect density $\left(N_{\mathrm{D}}, \mathrm{Cu} 2 \mathrm{O}\right)$ for different thicknesses of the $\mathrm{Cu}_{2} \mathrm{O}$ absorber layer

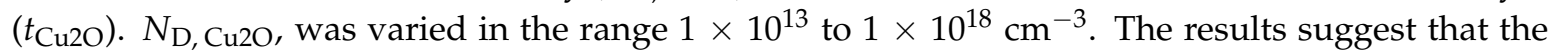

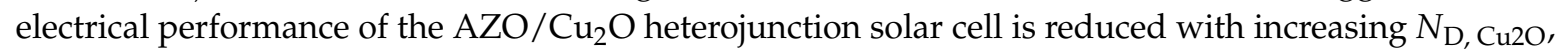
e.g., for $t_{\mathrm{Cu} 2 \mathrm{O}}=2 \mu \mathrm{m}$ the conversion efficiency decreases from $10.4 \%$ for $N_{\mathrm{D}, \mathrm{Cu} 2 \mathrm{O}}=1 \times 10^{14} \mathrm{~cm}^{-3}$ to $1.1 \%$ for $N_{\mathrm{D}, \mathrm{Cu} 2 \mathrm{O}}=1 \times 10^{17} \mathrm{~cm}^{-3}$. Figure $6 \mathrm{~b}$ shows the simulated I-V parameters for the $\mathrm{AZO} / \mathrm{Cu}_{2} \mathrm{O}$ heterojunction as a function of $N_{\mathrm{D}, \mathrm{Cu} 2 \mathrm{O}}$ for different IDL defect densities. The thickness of the interface defect layer was set to $5 \mathrm{~nm}$ in this simulation.
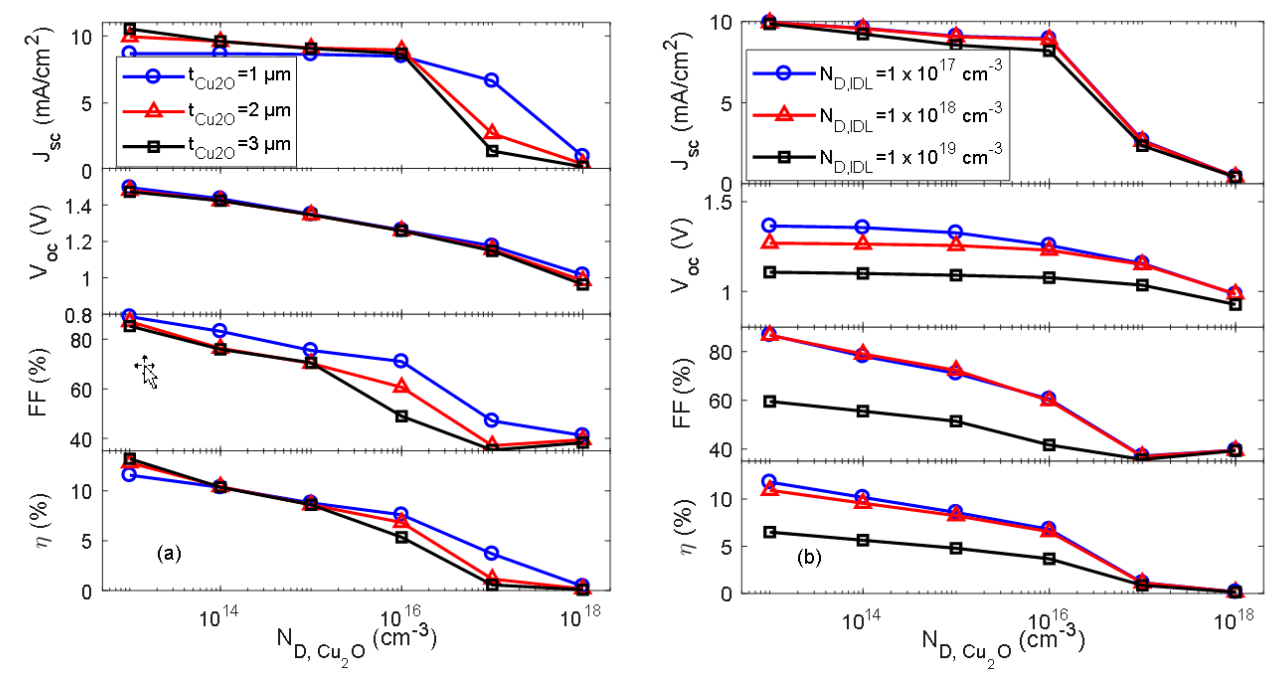

Figure 6. Simulated $\mathrm{I}-\mathrm{V}$ parameters for the $\mathrm{AZO} / \mathrm{Cu}_{2} \mathrm{O}$ heterojunction solar cell as a function of $N_{\mathrm{D}, \mathrm{Cu} 2 \mathrm{O}}$ for (a) various interface absorber layer thicknesses $\left(t_{\mathrm{Cu} 2 \mathrm{O}}\right)$ and (b) various defect densities in the interface defect layer (IDL) $\left(N_{\mathrm{D}, \mathrm{IDL}}\right)$ for $t_{\mathrm{IDL}}=5 \mathrm{~nm}$.

\section{Discussion on Heterojunction Interface Properties and Defect Analysis}

The numerical analysis shows that the buffer layer electron affinity has a big impact on the electrical performance of the $\mathrm{ZnO} / \mathrm{Cu}_{2} \mathrm{O}$ heterojunction solar cell. Figure 4 displays a distinct improvement in $V_{\mathrm{oc}}$ and FF as the buffer layer electron affinity is reduced from $\chi_{\mathrm{b}}=4.4 \mathrm{eV}$ to $\chi_{\mathrm{b}}=$ 
$3.7 \mathrm{eV}$, as a result of reduced conduction and valence band offsets giving a corresponding reduction of charge carrier recombination at the heterojunction interface. Additionally, the charge carrier collection is improved as a result of the suppressed interface recombination [11]. For $\chi_{b}=3.7 \mathrm{eV}$, a cliff-type conduction band offset $\Delta E_{\mathrm{CB}}=0.38 \mathrm{eV}$ is observed. Previous studies of the $\mathrm{ZnO} / \mathrm{Cu}_{2} \mathrm{O}$ heterojunction have indicated that a conduction band offset of $0.2-0.3 \mathrm{eV}$ yields the highest open circuit voltage $[8,9]$. To lower the conduction band offset for the $\mathrm{ZnO} / \mathrm{Cu}_{2} \mathrm{O}$ heterojunction solar cell there are several materials that can potentially be used as buffer layers, including $\mathrm{Ga}_{2} \mathrm{O}_{3}(\chi=4.0 \mathrm{eV}), \mathrm{TiO}_{2}(\chi=4.0 \mathrm{eV})$, $\mathrm{ZnS}(\chi=3.9 \mathrm{eV}), \mathrm{GaN}(\chi=3.5 \mathrm{eV}), \mathrm{Ta}_{2} \mathrm{O}_{5}(3.2 \mathrm{eV})$, and various $\mathrm{ZnO}$ alloys [11,18,19]. Many of these materials have been implemented as buffer layer in experimentally realized $\mathrm{ZnO} / \mathrm{Cu}_{2} \mathrm{O}$ heterojunction solar cells, but a relatively low performance has usually been achieved $[7,20]$. This suggests that manipulation of the energy band alignment at the heterojunction interface is most likely required, for instance by adjusting the deposition conditions, in addition to the incorporation of a buffer layer, in order to develop a high performance $\mathrm{ZnO} / \mathrm{Cu}_{2} \mathrm{O}$ heterojunction solar cell [9].

The energy band diagrams presented in Figure $5 b$ suggest that the defect density at the heterojunction interface affects the amount of band bending in the IDL and buffer layer, and the electrical performance of the $\mathrm{ZnO} / \mathrm{Cu}_{2} \mathrm{O}$ heterojunction solar cell is drastically reduced for an interface defect density $N_{D, I D L}>10^{18} \mathrm{~cm}^{-3}$, as shown in Figure $5 \mathrm{a}$. The concentration and charge transition energies of defects add restrictions to the position of the Fermi energy level in the materials, which may influence the energy band alignment at the heterojunction interface [9]. Thus, the alignment of the energy bands and the charge carrier transport and recombination at the heterojunction interface are dependent not only on the buffer layer affinity but also on electronic properties of the interfacial region of the $\mathrm{Cu}_{2} \mathrm{O}$ layer. The small enthalpy of formation for $\mathrm{Cu}_{2} \mathrm{O}$ means that $\mathrm{Cu}$ and $\mathrm{CuO}$ may easily be formed when the buffer layer is deposited onto the $\mathrm{Cu}_{2} \mathrm{O}$ surface. Typically, interfacial $\mathrm{Cu}$ will form a low barrier Schottky diode with $\mathrm{Cu}_{2} \mathrm{O}$, lowering the open circuit voltage of the heterojunction solar cell, whereas interfacial $\mathrm{CuO}$ could result in Fermi level pinning due to the low band gap $\left(E_{\mathrm{g}}=\right.$ $1.2 \mathrm{eV}$ ) of $\mathrm{CuO}$ [21]. It was previously found that the presence of $\mathrm{CuO}$ at the interface causes a $0.4 \mathrm{eV}$ shift in the valence-band offset between $\mathrm{Cu}_{2} \mathrm{O}$ and $\mathrm{ZnO}$, which may explain the large variation in the $\mathrm{ZnO} / \mathrm{Cu}_{2} \mathrm{O}$ valence-band offset reported in the literature $[9,21]$. Additionally, it was demonstrated a significantly higher $V_{\mathrm{OC}}$ for a $\mathrm{ZnO} / \mathrm{Cu}_{2} \mathrm{O}$ heterojunction solar cell with a stoichiometric $\left(\mathrm{Cu}_{2} \mathrm{O}\right)$ interface compared to that achieved with a mixed phase interface [21]. Thus, it is critical to be able to tune and control the oxidation state of copper oxide between $\mathrm{CuO}, \mathrm{Cu}_{2} \mathrm{O}$, and $\mathrm{Cu}$ at the $\mathrm{ZnO} / \mathrm{Cu}_{2} \mathrm{O}$ interface by carefully adjusting the deposition conditions during deposition of the buffer layer.

Figure 6 suggests that the performance of the $\mathrm{AZO} / \mathrm{Cu}_{2} \mathrm{O}$ heterojunction solar cell is significantly reduced with increasing bulk defect density in the $\mathrm{Cu}_{2} \mathrm{O}$ layer. The increased carrier recombination in the bulk of the absorber layer and at the heterojunction interface affects both the short circuit current and the open circuit voltage detrimentally, e.g., $J_{\mathrm{sc}}$ is reduced from approximately $9 \mathrm{~mA} / \mathrm{cm}^{2}$ for $N_{\mathrm{D}, \mathrm{Cu} 2 \mathrm{O}}=1 \times 10^{16} \mathrm{~cm}^{-3}$ to less than $1 \mathrm{~mA} / \mathrm{cm}^{2}$ for $N_{\mathrm{D}, \mathrm{Cu} 2 \mathrm{O}}=1 \times 10^{18} \mathrm{~cm}^{-3}$. This implies that controlling the bulk defect density during the thin film processing could also play an important role for the performance of the $\mathrm{ZnO} / \mathrm{Cu}_{2} \mathrm{O}$ heterojunction solar cell. The phase-purity and stoichiometry for the $\mathrm{Cu}_{2} \mathrm{O}$ absorber layer would ideally be controlled during the deposition process, but may also be modified by post-deposition processing such as thermal annealing or ion-implantation of for instance hydrogen or nitrogen. For example, passivation of donor-like defects has been reported by exposing $\mathrm{Cu}_{2} \mathrm{O}$ films to hydrogen plasma [22]. Experimental investigation of the $\mathrm{ZnO} / \mathrm{Cu}_{2} \mathrm{O}$ heterojunction has shown that the conduction and valence band offsets can indeed be altered by intrinsic defects and impurities, which suggests that controlling the interface formation during the fabrication process is critical to the device performance and functionality [9]. Such band alignment engineering of the metal oxide heterojunction, where the functional behavior can be tailored by the way the bands align at the interface, could potentially provide a pathway to realization of high-efficiency $\mathrm{ZnO} / \mathrm{Cu}_{2} \mathrm{O}$ heterojunction solar cells. 


\section{Conclusions}

In summary, the electrical characteristics of a metal oxide thin-film heterojunction solar cell based on a $\mathrm{Cu}_{2} \mathrm{O}$ absorber layer were investigated through numerical simulation using Silvaco Atlas. The electrical and optical properties of $\mathrm{AZO}$ and $\mathrm{Cu}_{2} \mathrm{O}$ thin films prepared on quartz substrates by magnetron sputter deposition were determined from spectroscopic ellipsometry and Hall effect measurements and implemented in the device model. The influence of the electronic properties of the heterojunction interface on the performance of an $\mathrm{AZO} / \mathrm{Cu}_{2} \mathrm{O}$ heterojunction solar cell was analyzed, and the results suggest that a conversion efficiency of more than $12 \%$ can be achieved when a buffer layer with electron affinity $\chi_{b}=3.7 \mathrm{eV}$ is inserted between the $\mathrm{AZO}$ transparent electrode and the $\mathrm{Cu}_{2} \mathrm{O}$ absorber layer. Thus, the sputter-deposited $\mathrm{Cu}_{2} \mathrm{O}$ thin films show good promise as absorber layer for photovoltaic applications. In order to develop a high performance $\mathrm{Cu}_{2} \mathrm{O}$-based heterojunction solar cell with a sufficiently low conduction band offset, manipulation of the energy band alignment at the heterojunction interface will most likely be required, for instance by adjusting the deposition conditions or by post-deposition treatment of the $\mathrm{Cu}_{2} \mathrm{O}$ layer, in addition to incorporation of a buffer layer. One of the main advantages of the magnetron sputtering technique, which has been used to synthesize the metal oxide thin films in this work, is that it provides good control of the stoichiometry of the films by varying the process parameters, such as substrate temperature, gas mass flows, and target power density, e.g., in order to obtain $\mathrm{Cu}$-rich or O-rich phases for $\mathrm{Cu}_{2} \mathrm{O}[12,16]$. This aspect, combined with the ability to control the electrical properties of the sputter-deposited thin films by rapid thermal annealing [17], suggests that it can indeed be possible to modify the band alignment at the interface to improve the electrical characteristics of the $\mathrm{AZO} / \mathrm{Cu}_{2} \mathrm{O}$ heterojunction. The impact of hydrogen ion-implantation and subsequent thermal annealing of the $\mathrm{Cu}_{2} \mathrm{O}$ layer on the electrical properties of the $\mathrm{AZO} / \mathrm{Cu}_{2} \mathrm{O}$ heterojunction will be the subject of further investigation. Additionally, further development of the numerical model to account for excitonic effects will be looked into. The traditional free carrier model has been reported not to accurately capture the fundamental photoconversion and charge-transport mechanism in $\mathrm{Cu}_{2} \mathrm{O}$, resulting in a significant underestimation of the conversion efficiency of $\mathrm{Cu}_{2} \mathrm{O}$-based heterojunction solar cells [23].

Author Contributions: Conceptualization, B.G.S., S.E.F., E.M., L.F., I.C., and Ø.N.; Methodology, Ø.N., C.D., D.C., F.D.; Formal Analysis, Ø.N.; Investigation, Ø.N., R.K., K.B., C.D., D.C., F.D.; Funding Acquisition, B.G.S., L.F., I.C., and Ø.N.; Software, Ø.N.; Validation, Ø.N., C.D., D.C., and F.D.; Resources, Ø.N.; Data Curation, Ø.N.; Writing-Original Draft Preparation, Ø.N.; Writing-Review \& Editing, Ø.N., K.B., L.F.; Visualization, Ø.N.; Supervision, Ø.N. and L.F.; Project Administration, Ø.N., B.G.S., and L.F.

Funding: This work was conducted under the research project "High-performance tandem heterojunction solar cells for specific applications (SOLHET)", funded by the Research Council of Norway (RCN), project no. 251789, and the Romanian Executive Agency for Higher Education, Research, Development and Innovation Funding (UEFISCDI), project no. 34/2016, through the M-Era.net program. RCN is also acknowledged for the support to the Norwegian Micro- and Nano-Fabrication Facility, NorFab, project no. 245963/F50.

Conflicts of Interest: The authors declare no conflict of interest.

\section{References}

1. International Technology Roadmap for Photovoltaic (ITRPV). Results 2017, 9th ed. September 2018. Available online: www.itrpv.net (accessed on 1 October 2018).

2. Nordseth, Ø.; Kumar, R.; Bergum, K.; Fara, L.; Foss, S.E.; Haug, H.; Drăgan, F.; Crăciunescu, D.; Sterian, P.; Chilibon, I.; Vasiliu, C.; et al. Optical Analysis of a $\mathrm{ZnO} / \mathrm{Cu}_{2} \mathrm{O}$ Subcell in a Silicon-Based Tandem Heterojunction Solar Cell. Green Sustain. Chem. 2017, 7, 57-69. [CrossRef]

3. Shockley, W.; Queisser, H.J. Detailed Balance Limit of Efficiency of PN Junction Solar Cells. J. Appl. Phys. 1961, 32, 510-519. [CrossRef]

4. Minami, T.; Nishi, Y.; Miyata, T. Efficiency enhancement using a $\mathrm{Zn}_{1-\mathrm{x}} \mathrm{Ge}_{\mathrm{x}}-\mathrm{O}$ thin film as an n-type window layer in $\mathrm{Cu}_{2} \mathrm{O}$-based heterojunction solar cells. Appl. Phys. Express 2016, 9, 052301. [CrossRef] 
5. Gan, J.; Gorantla, S.; Riise, H.N.; Fjellvåg, Ø.S.; Diplas, S.; Løvvik, O.M.; Svensson, B.G.; Monakhov, E.V.; Gunnæs, A.E. Structural properties of $\mathrm{Cu}_{2} \mathrm{O}$ epitaxial films grown on c-axis single crystal $\mathrm{ZnO}$ by magnetron sputtering. Appl. Phys. Lett. 2016, 108, 152110. [CrossRef]

6. Kramm, B.; Laufer, A.; Reppin, D.; Kronenberger, A.; Hering, P.; Polity, A.; Meyer, B.K. The band alignment of $\mathrm{Cu}_{2} \mathrm{O} / \mathrm{ZnO}$ and $\mathrm{Cu}_{2} \mathrm{O} / \mathrm{GaN}$ heterostructures. Appl. Phys. Lett. 2012, 100, 094102. [CrossRef]

7. Minami, T.; Nishi, Y.; Miyata, T. $\mathrm{Cu}_{2} \mathrm{O}$-based solar cells using oxide semiconductors. J. Semicond. 2016, 37, 014002. [CrossRef]

8. Brandt, R.E.; Young, M.; Park, H.H.; Dameron, A.; Chua, D.; Lee, Y.S.; Teeter, G.; Gordon, R.G.; Buonassisi, T. Band Offsets of N-Type Electron-Selective Contacts on Cuprous Oxide $\left(\mathrm{Cu}_{2} \mathrm{O}\right)$ for Photovoltaics. Appl. Phys. Lett. 2014, 105, 16-21. [CrossRef]

9. Siol, S.; Hellmann, J.C.; Tilley, S.D.; Graetzel, M.; Morasch, J.; Deuermeier, J.; Jaegermann, W.; Klein, A. Band alignment engineering at $\mathrm{Cu}_{2} \mathrm{O} / \mathrm{ZnO}$ heterointerfaces. ASC Appl. Mater. Interfaces 2016, 8, 21824. [CrossRef] [PubMed]

10. ATLAS User's Manual Device Simulation Software; Silvaco International Ltd.: Santa Clara, CA, USA, 2017.

11. Takiguchi, Y.; Miyajima, S. Device simulation of cuprous oxide heterojunction solar cells. Jpn. J. Appl. Phys. 2015, 54, 112303. [CrossRef]

12. Gan, J.; Venkatachalapathy, V.; Svensson, B.G.; Monakhov, E.V. Influence of Target Power on Properties of $\mathrm{Cu}_{\mathrm{x}} \mathrm{O}$ Thin Films Prepared by Reactive Radio Frequency Magnetron Sputtering. Thin Solid Films 2015, 594, 250-255. [CrossRef]

13. Wang, Y.; Miska, P.; Pilloud, D.; Horwat, D.; Mücklich, F.; Pierson, J.F. Transmittance enhancement and optical band gap widening of $\mathrm{Cu}_{2} \mathrm{O}$ thin films after air annealing. J. Appl. Phys. 2014, 115, 073505. [CrossRef]

14. Ishizuka, S.; Maruyama, T.; Akimoto, $\mathrm{K}$. Thin-film deposition of $\mathrm{Cu}_{2} \mathrm{O}$ by reactive radio-frequency magnetron sputtering. Jpn. J. Appl. Phys. 2000, 39, L786-L788. [CrossRef]

15. Lee, Y.S.; Winkler, M.T.; Siah, S.C.; Brandt, R.; Buonassisi, T. Hall mobility of cuprous oxide thin films deposited by reactive direct-current magnetron sputtering. Appl. Phys. Lett. 2011, 98, 192115. [CrossRef]

16. Nordseth, Ø.; Chilibon, I.; Kumar, R.; Bergum, K.; Vasiliu, C.; Iordanescu, R.; Baschir, L.; Savastru, D.; Kiss, A.; Parau, A.; Fara, L.; et al. Characterization of Cuprous Oxide Thin Films Prepared by Reactive Direct Current Magnetron Sputtering. Sens. Transducers 2018, 220, 37-44.

17. Bergum, K.; Riise, H.N.; Gorantla, S.; Lindberg, P.F.; Jensen, I.J.T.; Gunnæs, A.E.; Galeckas, A.; Diplas, S.; Svensson, B.G.; Monakhov, E. Improving carrier transport in $\mathrm{Cu}_{2} \mathrm{O}$ thin films by rapid thermal annealing. J. Phys. Condens. Matter 2018, 30, 075702. [CrossRef] [PubMed]

18. Tolstova, Y.; Omelchenko, S.T.; Blackwell, R.E.; Shing, A.M.; Atwater, H.A. Polycrystalline $\mathrm{Cu}_{2} \mathrm{O}$ photovoltaic devices incorporating $\mathrm{Zn}(\mathrm{O}, \mathrm{S})$ window layers. Sol. Energy Mater. Sol. Cells 2017, 160, 340-345. [CrossRef]

19. Lee, Y.S.; Heo, J.; Siah, S.C.; Mailoa, J.P.; Brandt, R.E.; Kim, S.B.; Gordon, R.G.; Buonassisi, T. Ultrathin amorphous zinc-tin-oxide buffer layer for enhancing heterojunction interface quality in metal-oxide solar cells. Energy Environ. Sci. 2013, 6, 2112-2118. [CrossRef]

20. Minami, T.; Miyata, T.; Nishi, Y. Relationship between the electrical properties of the n-oxide and p-Cu $2 \mathrm{O}$ layers and the photovoltaic properties of $\mathrm{Cu}_{2} \mathrm{O}$-based heterojunction solar cells. Sol. Energy Mater. Sol. Cells 2016, 147, 85-93. [CrossRef]

21. Wilson, S.S.; Bosco, J.P.; Tolstova, Y.; Scanlon, D.O.; Watson, G.W.; Atwater, H.A. Interface stoichiometry control to improve device voltage and modify band alignment in $\mathrm{ZnO} / \mathrm{Cu}_{2} \mathrm{O}$ heterojunction solar cells. Energy Environ. Sci. 2014, 7, 3606-3610. [CrossRef]

22. Ishizuka, S.; Kato, S.; Okamoto, Y.; Sakurai, T.; Akimoto, K.; Fujiwara, N.; Kobayashi, H. Passivation of defects in polycrystalline $\mathrm{Cu}_{2} \mathrm{O}$ thin films by hydrogen or cyanide treatment. Appl. Surf. Sci. 2003, 216, 94-97. [CrossRef]

23. Omelchenko, S.T.; Tolstova, Y.; Atwater, H.A.; Lewis, N.S. Excitonic effects in emerging photovoltaic materials: A case study in $\mathrm{Cu}_{2} \mathrm{O}$. ACS Energy Lett. 2017, 2, 431-437. [CrossRef]

(C) 2018 by the authors. Licensee MDPI, Basel, Switzerland. This article is an open access article distributed under the terms and conditions of the Creative Commons Attribution (CC BY) license (http:/ / creativecommons.org/licenses/by/4.0/). 